\title{
KANDUNGAN LEMAK DAN KOMPOSISI ASAM LEMAK OMEGA-3 PADA IKAN KAKAP MERAH (Aphareus furca)
}

\author{
Sofriani D. Bontjura ${ }^{1 *}$, Julius Pontoh ${ }^{1}$, Johnly A. Rorong ${ }^{1}$ \\ ${ }^{1}$ Program Studi Kimia, Fakultas Matematika dan Ilmu Pengetahuan Alam Universitas Sam Ratulangi \\ Jl. Kampus Unsrat, Kleak, Manado 05115 Sulawesi Utara
}

\begin{abstract}
ABSTRAK
Ikan laut merupakan sumber makanan penghasil terbesar asam lemak omega-3. Senyawa ini telah banyak dibuktikan memberikan efek positif bagi kesehatan. Telah dilakukan penelitian untuk mengetahui kadar lemak dan komposisi asam lemak omega-3 pada badan ikan kakap merah (Aphareus furca). Pengujian kadar lemak dilakukan menggunakan metode ekstraksi rendering. Ekstrak minyak ikan yang diperoleh ditransesterifikasi basa menggunakan metode derivatisasi dan diinjeksikan pada alat kromatografi gas. Bagian badan ikan kakap merah mengandung lemak sebesar $0,06 \%$. Kandungan asam lemak omega-3 sebesar $26,8 \%$ yang terdiri dari asam linolenat 2,4\%, eikosatrienoat 4,3\%, eikosapentaenoat (EPA) 0,9\% dan dokosaheksaenoat (DHA) 19,2\%.
\end{abstract}

Kata kunci: Asam lemak omega-3, kromatografi gas, ikan kakap merah

\begin{abstract}
Fishes are the biggest food source of omega- 3 fatty acids. This compound has been proven to have many positive effects on health. Research has been conducted to determine the fat content and composition of omega-3 fatty acids in the body of red snapper (Aphareus furca). Fat content testing is done using the rendering extraction method. Fish oil extract that was obtained were transesterified base using the derivatization method and injected on a gas chromatography device. The red snapper's body contains $0.06 \%$ fat. The omega- 3 fatty acid content is $26.8 \%$ consisting of $2.4 \%$ linolenic acid, $4.3 \%$ eicosatrienoic acid, $0.9 \%$ eicosapentaenoic acid (EPA) and $19.2 \%$ docosahexaenoic acid (DHA).
\end{abstract}

Keywords: Gas chromatography, omega-3 fatty acids, red snapper fish

\section{PENDAHULUAN}

Ikan merupakan sumber makanan yang banyak mengandung protein, lemak, vitamin dan mineral yang baik untuk tubuh manusia, serta penghasil terbesar asam lemak omega-3 (PUFA) khususnya eicosapentaenoic (EPA) dan docosahexaenoic (DHA), yang bermanfaat bagi kesehatan (Soccol \& Oetterer, 2003). Mengkonsumsi seafood dapat mencegah timbulnya berbagai penyakit dibanyak negara industri. Saat ini, beberapa senyawa fungsional dari ikan telah banyak dimanfaatkan dalam pangan fungsional antara lain omega-3 (PUFA), kalsium dari tulang ikan, karotenoid, dan vitamin D (Larsen dkk., 2011).

Komposisi kimia ikan sangat bervariasi, baik antar jenis satu dengan yang lain, antar individu dalam satu jenis, dan bahkan antar bagian-bagian tubuh dalam satu individu. Variasi itu disebabkan oleh adanya perbedaan jenis ikan, umur, ukuran, jenis kelamin, musim, jenis makanan dan suhu perairan saat ikan ditangkap (Suwetja, 2011).

Analisa asam lemak dapat dilakukan dengan berbagai metode analisa pemisahan seperti teknik isolasi dan kromatografi. Metode pemisahan yang paling umum digunakan pada analisa asam lemak menggunakan kromatografi gas. Menurut Hiltunen (2002), kromatografi gas telah menjadi teknik analisa yang menjadi langkah awal dalam aplikasi penetapan kadar asam lemak. Saat ini metode kromatografi gas dengan kolom kapiler memiliki sensitifitas dan keterulangan paling tinggi jika dikombinasikan dengan identifikasi spektrofotometri untuk menganalisa asam lemak.

Komposisi asam lemak dari lemak yang terdapat di dalam bagian-bagian tubuh ikan berbeda-beda (Pontoh, 2019). Menurut Jacoeb dkk (2015), kandungan asam lemak jenuh pada badan fillet ikan kakap merah segar adalah 17,43\% dan badan fillet ikan kakap merah goreng adalah $35,90 \%$. Kandungan asam lemak tak jenuh tunggal

\footnotetext{
Korespondensi:

Telepon: +62 851-0033-9759

E-mail: bontjurasofriani@gmail.com

DOI: https://doi.org/10.35799/cp.12.2.2019.27431
} 
pada badan fillet ikan kakap merah segar adalah 7,31\% dan badan fillet ikan kakap merah goreng adalah $34,48 \%$. Kandungan asam lemak tak jenuh ganda pada badan fillet ikan kakap merah segar adalah 10,8\% dan badan fillet ikan kakap merah goreng adalah $11,66 \%$. Berdasarkan hal tersebut di atas, peneliti tertarik untuk melakukan analisa kandungan lemak dan komposisi asam lemak omega-3 pada ikan kakap merah dengan menggunakan kromatografi gas. Hasil penelitian ini diharapkan bermanfaat bagi ilmu pengetahuan untuk dapat mengembangkan penelitian tentang bahan alami penghasil lemak ikan juga dapat memberikan informasi pada masyarakat tentang nilai nutrisi ikan kakap merah. Tujuan penelitian ini adalah untuk mengetahui kandungan lemak dan komposisi asam lemak omega-3 pada ikan kakap merah.

\section{BAHAN DAN METODE}

\section{Alat dan bahan}

Alat-alat yang digunakan yaitu, pisau, talenan, kompor gas, panci stainless steel, botol transparan $600 \mathrm{~mL}$, kaca arloji, pipet tetes, tabung reaksi, sentrifuge, botol vial, corong, timbangan analitik, aluminium foil, tisu, seperangkat alat kromatografi gas (Shimadzu GC-2014), pipet volumetrik, labu takar, gelas ukur. Bahan-bahan yang digunakan yaitu, sampel ikan kakap merah yang diperoleh dari pasar tradisional bersehati di kota Manado. Bahan kimia yang digunakan yaitu metanol, $\mathrm{NaOH}$, aquades, heksan, asam asetat dan Supelco 37 component FAME Mix (standar).

\section{Ekstraksi dan penetapan kadar lemak}

Ikan dibersihkan dari sisiknya kemudian dipotong untuk memisahkan kepala, jeroan dan badan, selanjutnya bagian-bagian tersebut diblender. Sampel yang sudah diblender dipindahkan ke panci stainless steel dan ditambahkan air 2 kali volume sampel. Sampel direbus selama sekitar 1 jam dan ditambahkan air untuk menjaga volume air konstan. Selanjutnya sampel dibiarkan dingin, diambil dan dimasukkan ke dalam botol transparan $600 \mathrm{~mL}$ dengan leher sempit panjang. Setelah kaldu berada di dalam botol, fraksi lemak menumpuk di bagian atas kaldu. Lemak disalurkan ke tabung sentrifugasi kemudian disentrifugasi selama 15 menit. Lemak dipisahkan dan dikumpulkan untuk analisa lebih lanjut. Kandungan lemak dihitung sebagai berat lemak dibagi dengan berat sampel segar waktu $100 \%$. Kadar lemak (\%) dapat dihitung dengan rumus: berat minyak/berat sampel x $100 \%$.

\section{Penetapan kadar air (Sudarmadji, 1989)}

Sebanyak 3 g sampel dimasukkan ke dalam oven pada suhu $105^{\circ} \mathrm{C}$ selama 3-5 jam, kemudian dikeluarkan dari oven dan didinginkan dalam desikator selama 30 menit, setelah itu sampel ditimbang. Perlakuan ini dilakukan beberapa kali hingga berat sampel konstan. Kadar air dihitung berdasarkan rumus:

$$
\frac{\text { berat awal sampel - berat akhir sampel }}{\text { berat awal sampel }} \times 100 \%
$$

dimana a berat awal sampel $(\mathrm{g}), \mathrm{b}=$ berat akhir sampel (g)

\section{Analisa asam lemak}

\section{Derivatisasi (Christie, 1989)}

Sampel $50 \mathrm{mg}$ dilarutkan dalam $1 \mathrm{~mL}$ heksan kemudian ditambahkan $2 \mathrm{~mL} \mathrm{NaOH}$ methanol 0,5 M selanjutnya dipanaskan selama 10 menit pada suhu $50^{\circ} \mathrm{C}$ setelah itu didinginkan dan ditambahkan $0,1 \mathrm{~mL}$ asam asetat dan $5 \mathrm{~mL}$ aquades. Lapisan atas dipindahkan ke dalam botol vial kemudian lapisan bawah diekstrak dengan heksan sebanyak 2 kali $5 \mathrm{~mL}$. Diambil lapisan atas yang terbentuk dan dimasukkan ke dalam botol vial. Dari botol diambil sebanyak $1 \mu \mathrm{L}$ untuk dianalisa pada GC.

\section{Analisa kromatografi gas (Pontoh, 2016)}

Analisa kromatografi dilakukan menggunakan Shimadzu Gas Chromatography (GC-2014) dengan Flame Ionization Detector (FID) dan Kolom Thermo Scientific (TR-FAME) dengan panjang $30 \mathrm{~m}$, diameter $0,25 \mathrm{~mm}$, ketebalan film $0,25 \mu \mathrm{m}$. Suhu kolom dari $120^{\circ} \mathrm{C}$ selama 7 menit lalu meningkat sampai $250{ }^{\circ} \mathrm{C}$ dengan jalannya suhu $10^{\circ} \mathrm{C} /$ menit dan selama 20 menit suhu konstan sebesar $250{ }^{\circ} \mathrm{C}$. Suhu detektor $270{ }^{\circ} \mathrm{C}$, suhu injeksi dipanaskan pada $260{ }^{\circ} \mathrm{C}$, dilengkapi dengan injektor split-pisah dengan 1/10 dan tekanan gas pembawa helium diatur pada 75 $\mathrm{kPa}$. Satu mikroliter sampel dimasukkan ke tempat injeksi.

\section{Penentuan kandungan asam lemak}

Waktu retensi asam-asam lemak dari lemak ikan ditentukan berdasarkan waktu retensi asamasam lemak standar Supelco 37 component FAME Mix. Komposisi asam-asam lemak dalam lemak ikan ditentukan berdasarkan jumlah luas puncak metil ester asam-asam lemak dibagi total luas puncak dikali $100 \%$. Rumus persen luas puncak:

$\frac{\text { Luas puncak metil ester asam-asam lemak }}{\text { Total luas puncak asam-asam lemak }} \chi 100 \%$ 


\section{HASIL DAN PEMBAHASAN}

\section{Kadar air}

Air berfungsi sebagai bahan yang dapat mendispersikan senyawa yang terdapat dalam bahan makanan. Untuk beberapa bahan, air berfungsi sebagai pelarut. Air dapat melarutkan berbagai bahan seperti garam, vitamin yang larut dalam air, mineral dan senyawa cita rasa. Banyaknya kandungan air dalam bahan pangan merupakan salah satu faktor yang mempengaruhi kecepatan dan aktifitas enzim, aktifitas mikroba dan aktifitas kimiawi, yaitu terjadi ketengikan, reaksi non enzimatis sehingga menimbulkan sifatsifat organoleptik, penampakan, tekstur dan cita rasa gizi yang berubah (Amanu, 2014).

Kadar air adalah hilangnya berat ketika bahan dikeringkan sesuai dengan teknik atau metode tertentu. Kadar air adalah perbedaan antara berat bahan sebelum dan sesudah dilakukan pemanasan (Sudrajat, 2009).

Ikan atau sejenisnya mempunyai komposisi kimia yang berbeda, tetapi pada dasarnya senyawa kimia terbesar yang ada di dalam ikan adalah air. Ikan kakap memiliki kadar air sebesar $76,98 \pm 0,78 \%$. Menurut Sunarya (1996), besarnya kadar air dari ikan segar berkisar antara 70-80\% dan kadar lemak 0-20\%. Besarnya variasi kandungan bahan kimia tersebut sangat dipengaruhi oleh beberapa faktor seperti jenis ikan, seks (jenis kelamin), umur ikan, musim dan kondisi dimana ikan tersebut hidup.

\section{Kadar lemak}

Berbeda dengan jenis lemak yang berasal dari hewan atau tumbuhan darat, lemak yang terdapat dalam ikan atau sejenisnya terdiri dari trigliserida yang mempunyai ciri-ciri khas yaitu: mengandung banyak jenis asam lemak, banyak ikatan rangkap (senyawa tidak jenuh) dan asam lemak dengan atom $\mathrm{C}$ yang panjang misalnya 22 atau 24 atom C. Di lain pihak lemak dari ikan relatif banyak mempunyai nilai gizi yang sangat berbeda yaitu adanya asam lemak jenis omega-3 dapat mencegah kolesterol dalam pembuluh darah terutama arteri yang dapat dipakai sebagai bahan pencegah terjadinya penyakit jantung karena arteriosklerosis (Sunarya, 1996).

Kadar lemak ikan kakap merah dibagian badan sebanyak 0,06\%. Menurut Jacoeb dkk., (2015) kadar lemak fillet kakap merah segar sebesar $0,23 \%$. Kadar lemak yang rendah dari jaringan ikan dalam percobaan ini bisa jadi karena metode ekstraksi menggunakan air mendidih dibandingkan dengan percobaan sebelumnya menggunakan metanol dan kloroform (Pontoh, 2019).

Kandungan lemak dapat bervariasi di setiap bagian tubuh ikan tergantung pada pergerakan, habitat perairan dan sumber pakan (Nakamura dkk., 2007). Komposisi kimia ikan sangat bervariasi, baik antar jenis satu dengan yang lain, antar individu dalam satu jenis, dan bahkan antar bagian-bagian tubuh dalam satu individu. Variasi itu disebabkan oleh adanya perbedaan jenis ikan, umur, ukuran, jenis kelamin, musim, jenis makanan dan suhu perairan saat ikan ditangkap (Suwetja, 2011).

\section{Penentuan asam-asam lemak}

Untuk mengetahui retention time metilmetil ester, maka dilakukan analisa terhadap zat standar Supelco 37 component FAME mix yang hasilnya terlihat pada gambar 9. Hasil kromatogram terpisah dengan baik dan digunakan sebagai panduan dalam menentukan metil ester apa saja yang terdapat dalam sampel. Kromatogram Gambar 5 menunjukkan 35 puncak yang muncul dikarenakan asam-asam lemak tumpang tindih dalam satu puncak. Hal ini juga dilaporkan oleh (Khan, 2013) yang menggunakan kolom dan standar yang sama. Puncak yang tumpang tindih adalah asam lemak eikosadienoat (C20:3) dan asam lemak erukat (C22:1). Puncak yang terlihat jelas pada badan kakap adalah palmitat, DHA, oleat, stearat, trikosanoat, eikosatrienoat, palmitoleat dan miristat.

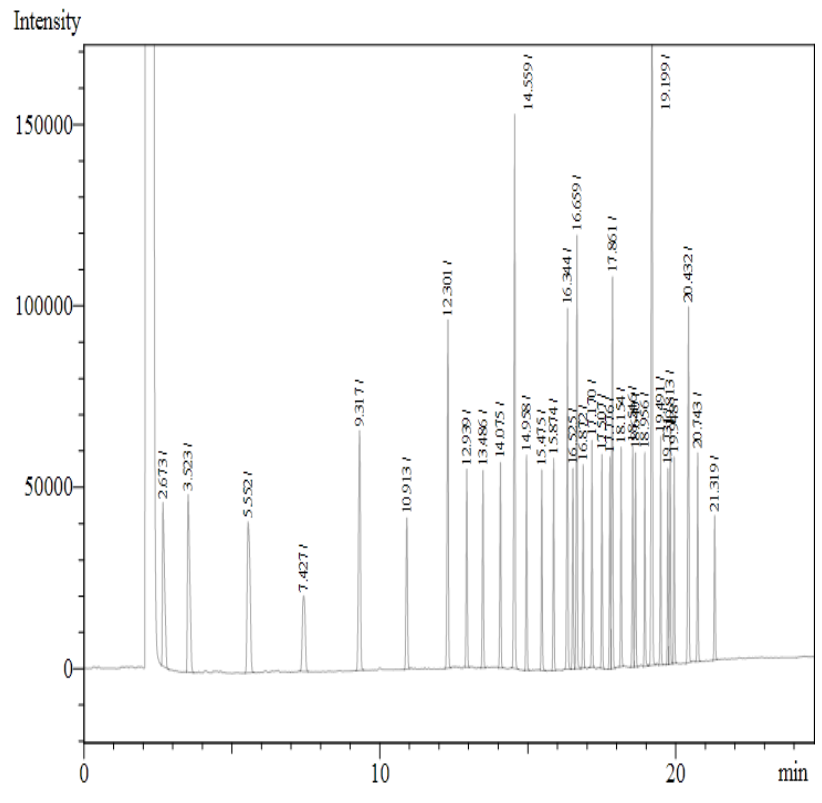

Gambar 1. Kromatogram larutan standar Supelco FAME Mix 


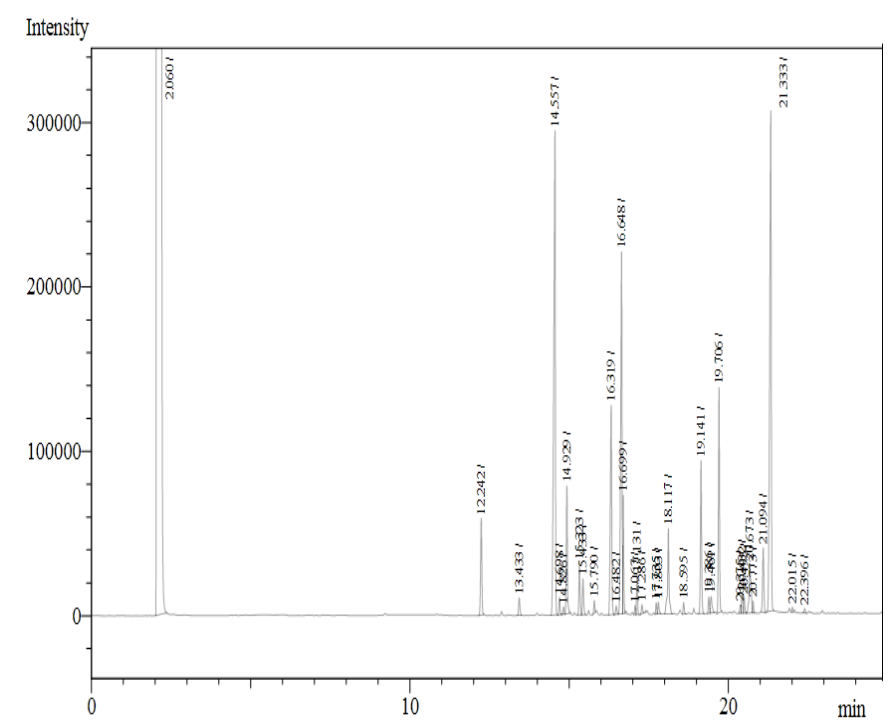

Gambar 2. Kromatogram badan ikan kakap

Badan ikan kakap mengandung 23 jenis asam lemak di antaranya adalah asam lemak palmitat $23,1 \%$ diikuti DHA $19,2 \%$ dan oleat $15,9 \%$. Ikan kakap kaya akan asam lemak omega3 khususnya DHA. Lemak ikan kaya akan PUFA omega-3, terutama asam eikosapentaenoat (EPA; C20:5) dan asam docosahexaenoic (DHA; C22:6). Pentingnya PUFA dalam kesehatan manusia dan nutrisi dikenal dengan baik. Banyak klinis dan studi epidemiologi telah menunjukkan peran positif untuk omega-3 PUFA dalam perkembangan bayi, kanker, penyakit kardiovaskular, dan baru-baru ini dalam berbagai penyakit mental, termasuk depresi, gangguan pemusatan perhatian, hiperaktivitas, dan demensia (Riediger dkk., 2009).

Perbedaan asam lemak ikan tidak hanya harus dipertimbangkan sehubungan dengan habitat spesies tetapi juga berdasarkan pada mereka didkkami terutama apakah suatu spesies herbivora, omnivora atau karnivora (Sargent, dkk., 1995). Terlepas dari itu, ukuran, usia, reproduksi status ikan, kondisi lingkungan, terutama suhu air mempengaruhi kadar lemak dan asam lemak komposisi otot ikan sampai batas tertentu (Ackman, 1989; Saito dkk., 1999).

Total SFA pada setiap sampel lebih besar dibandingkan dengan total MUFA dan PUFA (Minarny dkk., 2014). SFA yang paling dominan adalah asam palmitat (Ozogul, 2007). Osman dkk., (2001) menyatakan bahwa palmitat merupakan asam lemak jenuh yang paling banyak terdapat dalam lemak ikan. Asam lemak MUFA yang paling dominan pada semua sampel adalah asam oleat. Asam oleat adalah penyusun utama MUFA,
$58-74 \%$ dari total MUFA untuk ikan air laut sementara itu memberikan kontribusi 22-70\% dari total MUFA untuk ikan air tawar (Ozogul, 2007). Asam lemak PUFA khususnya omega-3 merupakan asam lemak yang paling banyak diteliti dalam lemak ikan karena dipercaya memiliki banyak manfaat bagi kesehatan (Sun dkk., 2002) (Osman dkk., 2001).

Tabel 1. Komposisi asam-asam lemak yang tekandung dalam badan ikan kakap (*adalah omega-3)

\begin{tabular}{lll}
\hline Asam Lemak & Nama & Kakap $(\%)$ \\
\hline C14:0 & Miristat & $3,6 \pm 0,3$ \\
C15:0 & Pentadekanoat & $0,8 \pm 0,2$ \\
C16:0 & Palmitat & $23,1 \pm 1,1$ \\
C17:0 & Heptadekanoat & $1,6 \pm 0,1$ \\
C18:0 & Stearat & $8,9 \pm 0,9$ \\
C20:0 & Arakidat & $0,3 \pm 0,0$ \\
C23:0 & Trioksanoat & $5,0 \pm 1,4$ \\
Total SFA & & 43,3 \\
C16:1 & Palmitoleat & $4,6 \pm 1,1$ \\
C17:1 & Heptanoat & $0,4 \pm 0,1$ \\
C18:1 T & Elaidat & $0,3 \pm 0,0$ \\
C18:1 C & Oleat & $15,9 \pm 2,7$ \\
C20:1 & Eikosenoat & $0,5 \pm 0,1$ \\
C22:1 & Erukat & $1,0 \pm 0,6$ \\
C24:1 & Nervonat & $2,9 \pm 0,6$ \\
Total MUFA & & 25,6 \\
C18:2 T & Linolelaidat & $3,2 \pm 0,5$ \\
C18:2 C & Linoleat & $1,5 \pm 0,4$ \\
C18:3 Cis 6 & gama Linolenat & $0,6 \pm 0,0$ \\
C18:3 Cis 9* & Linolenat & $2,4 \pm 0,9$ \\
C20:2 C & Eikosadienoat & $0,4 \pm 0,1$ \\
C20:3 C * & Eikosatrienoat & $4,3 \pm 0,5$ \\
C20:4 & Arakidonat & $0,8 \pm 0,1$ \\
C20:5 $*$ & EPA & $0,9 \pm 0,2$ \\
C22:6 $*$ & DHA & $19,2 \pm 3,1$ \\
Total PUFA & & 33,3 \\
Total Omega-3 & & 26,8 \\
\hline & &
\end{tabular}

\section{KESIMPULAN}

Kandungan lemak pada badan ikan kakap adalah 0,06\%. Asam-asam lemak utama penyusun lemak pada badan ikan kakap secara berturut-turut adalah palmitat, dokosaheksaenoat, dan oleat. 
Kandungan asam lemak omega-3 pada ikan kakap adalah asam linolenat, eikosatrienoat, eikosapentaenoat (EPA) dan dokosaheksaenoat (DHA). Konsentrasi asam lemak omega-3 pada ikan kakap 26,8\%.

\section{DAFTAR PUSTAKA}

Ackman, R.G. 1989. Nutritional composition of fats in seafoods. Progress in Food and Nutrition Science. 13(3-4), 161-241.

Amanu, F.N. 2014. Pembuatan tepung mocap di Madura (kajian vanetas dan lokasi penanaman) terhadap mutu dan rendemen. Jurnal Pangan dan Ogroindustri. 2(3), 161169.

Christie, W.W. 1989. Gas chromatography and lipids: A practical guide. Scotland: The Oily Press.

Hiltunen, R. 2002. Review: Analysis fatty acid by gas chromatography, and its relevance to research on health and nutrition. Analytical Chimica Acta. 465(1-2), 39-62.

Jacoeb, A.M., Suptijah, P. \& Kristantina, W.A. 2015. Komposisi asam lemak, kolesterol, dan deskripsi jaringan fillet ikan kakap merah segar dan goreng. Jurnal Pengolahan Hasil Perikanan Indonesia. 18(1), 98-107.

Khan, A.I. 2013. A GC-FID method for the comparison of acid and base catalyzed derivatization of fatty acids to FAMEs in three edible oils. Runcorn: Thermo Fisher Scientific.

Larsen, R., Eilersten, K.E. \& Elvevoll, E.O. 2011. Health benefits of marine foods and ingredients. Biotechnology Advances. 29(5), 508-518.

Minarny, G., Purnomo, H., Asriani \& Rosyidi, D. 2014. Fatty acid profile of fish from Central Sulawesi, Indonesia. International Food Research Journal. 21(3), 979-983.

Nakamura, Y., Ando, M., Seoka, M., Kawasaki, K. \& Tsukamasa, Y. 2007. Changes of proximate and fatty acid compositions of the dorsal and ventral ordinary muscles of the full-cycle cultured Pacific bluefin tuna Thunnus orientalis with the growth. Food Chemistry. 103(1), 234-241.

Osman, H., Suriah, A.R. \& Law, E.C. 2001. Fatty acid composition and cholesterol content of selected marine fish in Malaysian water. Food Chemistry. 75(1), 55-60.

Ozogul, Y., Ozogul, F. \& Alagoz,S. 2007. Fatty acid profiles and fat contents of commercially important seawater and freshwater fish species of Turkey: A comparative study. Food Chemistry. 103(1), 217-223.

Pontoh, J. 2016. Gas chromatographic analysis of medium chain fatty acids in coconut oil. Journal of Pure and Applied Chemistry Research. 5(3), 157-161.

Pontoh, J. 2019. Extraction and characterization of fish oil from various parts of Snakehead fish (Chana striate). International Journal of Chemistry Technology Research. 12(1), 323-328.

Riediger, N.D., Othman, R.A., Suh, M. \& Moghadasian, M.H. 2009. A systemic review of the roles of $n-3$ fatty acids in health and disease. Journal of the American Dietetic Association. 109(4), 668-679.

Saito, H., Yamashiro, R., Alasalvar, C. \& Konno, T. 1999. Influence of diet on fatty acids of three subtropical fish, subfamily Caesioninae (Caesio diagramma and $C$. tile) and family Siganidae (Siganus canaliculatus). Lipids. 34(10), 1073-1082.

Sargent, J.R., Bell, J.G., Bell, M.V., Henderson, R.J. \& Tocher, D.R. 1995. Requirements criteria for essential fatty acids. Journal of Applied Ichthyology. 11(34), 183-198.

Soccol, M.C.H. \& Oetterer, M. 2003. Seafood as functional foods. Brazilian archives of' Biology and Technology. An International Journal. 46(3), 443-454.

Sudarmadji, S., Haryono, B. \& Suhardi. 1989. Prosedur Analisa untuk Bahan Makanan dan Pertanian. Yogyakarta: Liberty.

Sudrajat, D.J. 2009. Pengembangan standar pengujian kadar air dan perkecambahan benih beberapa jenis tanaman hutan untuk menunjang program penanaman hutan di daerah. Jurnal Litbang Pertanian. 23(2), 13-19.

Sun, T., Pigott, G.M. \& Herwig, R.P. 2002. Lipase-assisted concentration of $n-3$ polyunsaturated fatty acids from viscera of farmed Atlantic Salmon (Salmo salar L.). Journal Of Food Science. 67(1), 130-136.

Sunarya. 1996. Proses Kemunduran Mutu Hasil Perikanan dan Persyaratan Mutu Bahan Baku. Jakarta: Pusat Pelatihan Ekspor Indonesia Departemen Perindustrian dan Perdagangan.

Suwetja, I.K. 2011. Biokimia Hasil Perikanan. Media Prima, Aksara Jakarta. 